\title{
New I-V Characteristics Scan-Type MPPT Control Method for PV Generation System
}

\author{
Kazutaka Itako*
}

Kanagawa Institute of Technology, 1030 Shimo-Ogino, Atsugi, Kanagawa 243-0292, Japan

\begin{abstract}
This paper proposes the new scanning interval control method in I-V characteristics scan-type MPPT control for a PV generation system. From the experimental results, it is clarified that even if the value of $L$ is low, the set detecting interval can be assured regardless of difference of the solar radiation intensity, and that the new MPPT control offers outstanding effectiveness in partially shaded environments.
\end{abstract}

Keywords: MPPT, PV Generation Systems, Renewable Energy Systems, DSP, DC-DC Converter, PWM.

\section{INTRODUCTION}

Photovoltaic sources are used today in many applications such as battery charging, home power supply (Grid-Connected System [1]) and satellite power systems etc. They require a power conditioner ( $\mathrm{dc} / \mathrm{dc}$ or dc/ac converter) for load interface. Since PV modules still have relatively low conversion efficiency, the overall system cost can be reduced using high efficiency power conditioners which, in addition, are designed to extract the maximum possible power from the PV module. Therefore, various MPPT (Maximum Power Point Tracking) methods have been investigated [2-7]. A very popular MPPT technique is $\mathrm{P} \& \mathrm{O}$ method. A small increase or decrease in the PV voltage $V_{P V}$ would result in no change in the power output $p_{P V}$, as the peak point locally lies in a flat neighborhood. The $\mathrm{PV}$ voltage $\mathrm{V}_{\mathrm{PV}}$ is maintained at the level where $\Delta \mathrm{p}_{\mathrm{PV}} / \Delta \mathrm{v}_{\mathrm{PV}}$ is close to zero. Despite the good adaptiveness of this technique, the response for the solar radiation change is slow due to one-dimensional seeking. Furthermore, for a partial shadow, the operation of this method is unstable.

Therefore, the author proposed an alternative MPPT control method in a PV generation system [812]. This proposed method has the extremely high MPPT efficiency due to scanning the I-V characteristics periodically. However, in this method, because the I-V characteristics scanning interval is extremely short (a few hundred microsecond) on the practical value (a few hundred micro henrys) of boost inductance $L$, there is never enough time for $A / D$ conversion.

In response to this concern, this paper proposes the new scanning interval control method in $\mathrm{I}-\mathrm{V}$

*Address corresponding to this author at the Kanagawa Institute of Technology, 1030 Shimo-Ogino, Atsugi, Kanagawa 243-0292, Japan;

Tel/Fax: +81-46-291-3152; E-mail: itako@ele.kanagawa-it.ac.jp characteristics scan-type MPPT control for a PV generation system [13].

\section{PROPOSED CONTROL SYSTEM}

Figure 1 shows the circuit configuration of the proposed control system. In this figure, $L$ denotes the smoothing inductor. The solar cell is connected in series or parallel to the required power level. The power from the solar cell, whose voltage is boosted by a step-up DC-DC converter, is then applied to the load. The control system detects the solar cell voltage $v_{P V}$ and the solar cell current $\mathrm{i}_{\mathrm{PV}}$ in real time. And these values then undergo an $A / D$ conversion. Figure 2 displays a conceptual diagram that depicts the operational waveforms for this control method. The carrier wave (serrated wave) is compared to the reference signal wave using a comparator, which yields the PWM control signal. When the maximum power $P_{\max }$ is detected, by the PWM control, the solar cell current $i_{P V}$ is assumed to be zero when the solar cell voltage $V_{P V}$ is equal to the open voltage $V_{O C}$. Next, the system transitions into the $P_{\max }$ detection interval. In this state, the $i_{P V}$ is controlled to the following reference current $\mathrm{I}_{\mathrm{PV} \text { ref }}$ by the PWM control.

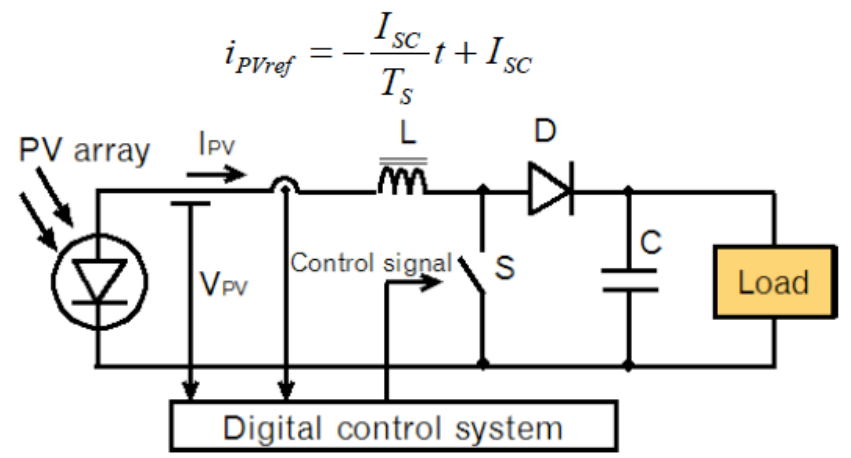

Figure 1: Circuit configuration.

Where, $I_{S C}$ is a short circuit current $[A]$ and $T_{S}$ is IV characteristics scanning interval[s]. Changes in the 


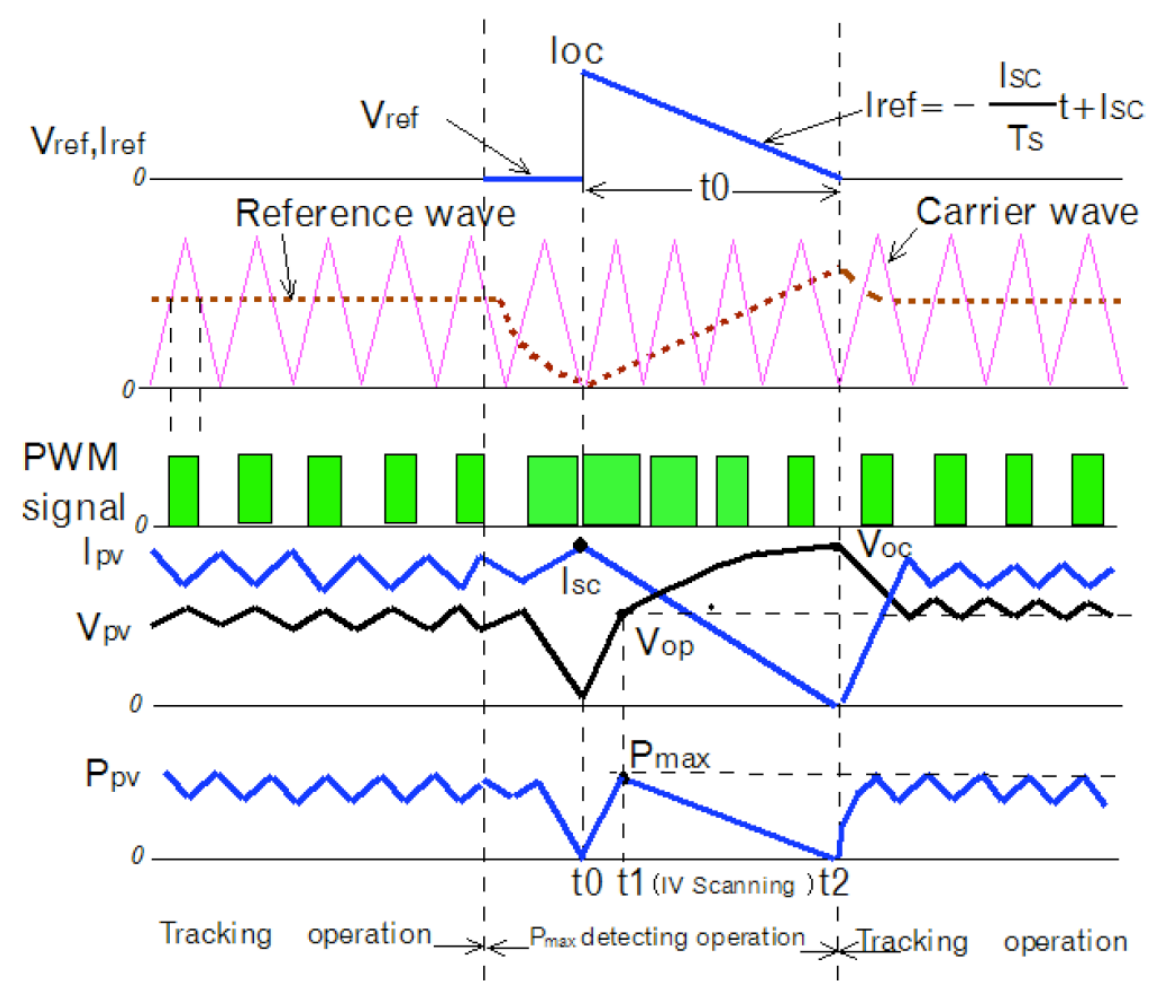

Figure 2: Operational waveforms.

solar cell's output power can be exploited to identify the optimal operating voltage $\mathrm{V}_{\mathrm{OP}}$ at the maximum power point. In this period, the solar cell current $\mathrm{i}_{\mathrm{PV}}$ is multiplied by the measured solar cell voltage $v_{P V}$ to determine the maximum power point. Because in the method of [8-12], these operations are conducted by $\mathrm{ON}$ and OFF of $S$, the detection time depends on $L$ and the solar radiation intensity. Hereafter, the solar cell voltage $\mathrm{V}_{\mathrm{PV}}$ is controlled to trail the resulting optimal operating voltage $V_{O P}$. The final step, the tracking operation interval, involves switching at a high frequency $f_{C}\left(=1 / T_{C}\right)$, in the range of tens of $k H z$, in order to regulate the output voltage of the DC-DC converter. The output voltage is controlled so that the solar cell voltage $v_{P V}$ is equal to the optimal operating voltage $V_{O P}$. It is possible to obtain the maximum power possible under the current conditions by sequentially performing the maximum power point detection operation and the tracking operation for a fixed number of cycles $T$. It should be noted that the impact of these intervals on the power acquisition capacity is negligibly small because the $P_{\max }$ detection interval is sufficiently small relative to the detection cycle $T$, and can be therefore ignored.

\section{EXPERIMENTAL RESULTS}

The nominal optimum operating voltage and current for the solar cell panel are $15.8 \mathrm{~V}$ and $3.16 \mathrm{~A}(50 \mathrm{~W})$, respectively. Two panels were connected in parallel. The DC-DC converter had constants of $L=800 \mu \mathrm{H}$ and, $\mathrm{C}=1000 \mu \mathrm{F}$. As a load, electronic load (24V:constant voltage mode) was used. The switching frequency $f_{C}$ was set to $100 \mathrm{kHz}$ and the detection cycle $\mathrm{T}$ was set to $1.0 \mathrm{~s}$. A digital signal processor (DSP) was used to control the computational processing. The vertical axis resolution for the $A D$ converter was 12 bits with a sampling frequency of $100 \mathrm{kHz}$.

Figure (3a) and (b) show the detecting waveforms without detecting interval control. These figures confirm the detecting interval is changed by the solar radiation intensity $\mathrm{G}$. And these intervals are short. Figure 4, 5 and 6 show the detecting waveforms $\left(T_{S}=3.0,5.0\right.$ and $10.0 \mathrm{~ms}$ ) of proposed method. These figures demonstrate the set detecting interval $T_{S}$ can be assured regardless of difference of the solar radiation intensity G.

Figure 7 shows the P-V characteristic and Figure 8 shows the operating waveforms when partial shading is applied one of the two serially connected photovoltaic panels(the solar radiation intensity $G=1000\left[\mathrm{~W} / \mathrm{m}^{2}\right]$ ). With the proposed MPPT control method, Figure (8a) shows that the maximum power point on the lowvoltage side is tracked when partial shading is applied. However, with the conventional P\&O method, Figure (8b) shows that the low peak of power is tracked on the 


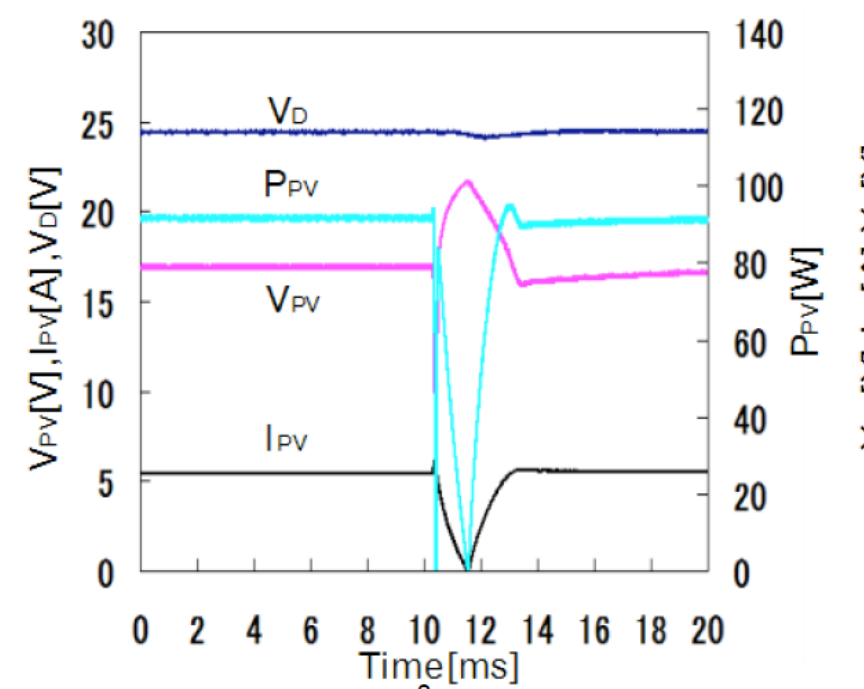

(a) $\mathrm{G}=872\left[\mathrm{~W} / \mathrm{m}^{2}\right]$.

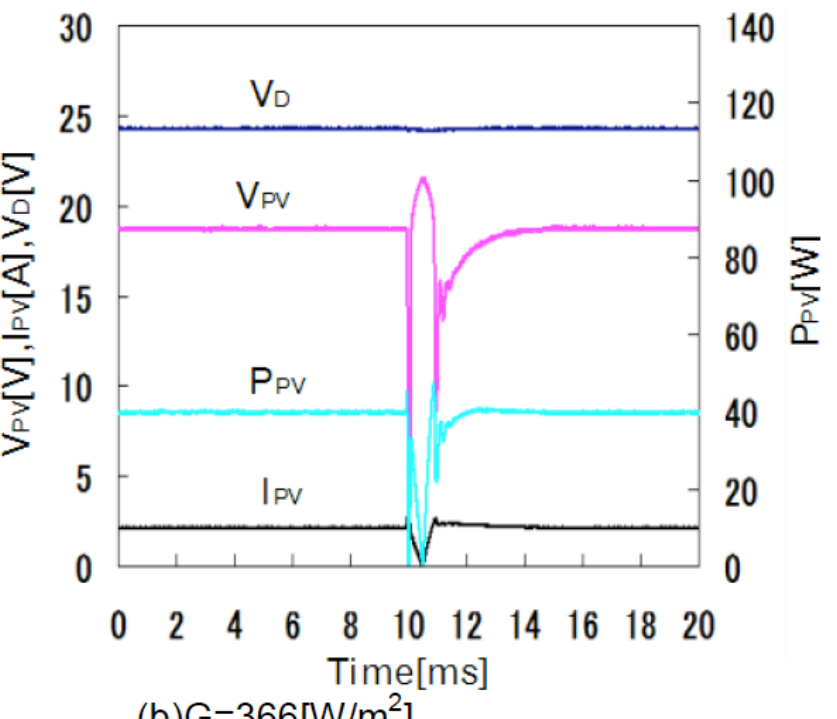

(b) $G=366\left[\mathrm{~W} / \mathrm{m}^{2}\right]$.

Figure 3: Detecting waveforms without detecting interval control.

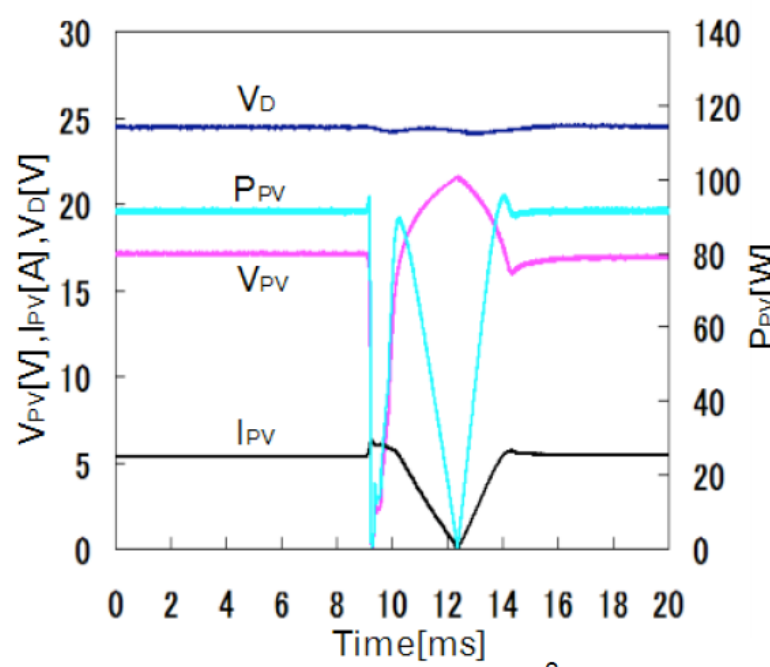

(a) $\mathrm{G}=880\left[\mathrm{~W} / \mathrm{m}^{2}\right]$.

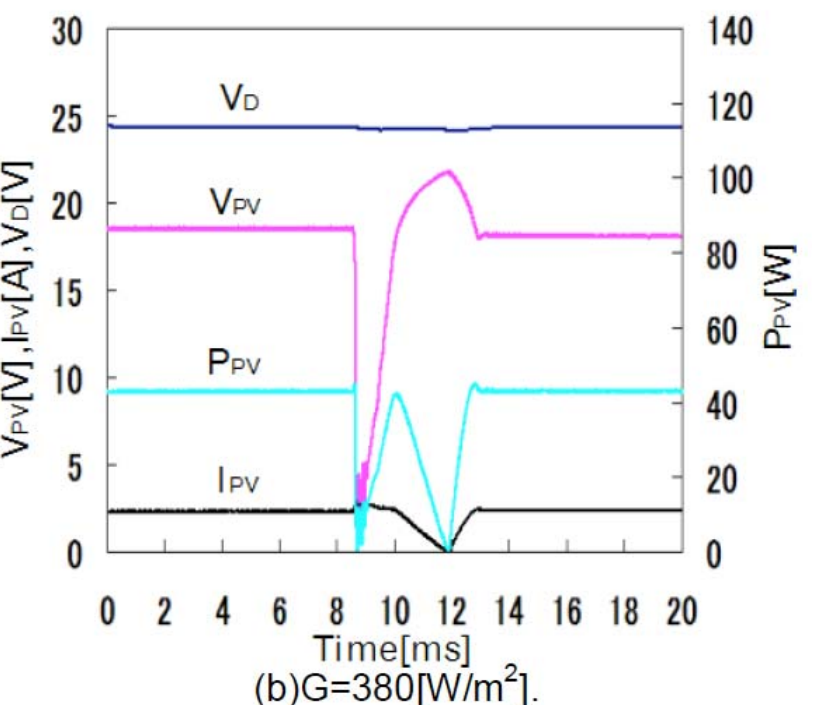

Figure 4: Detecting waveforms (Ts=3.0 [ms]).

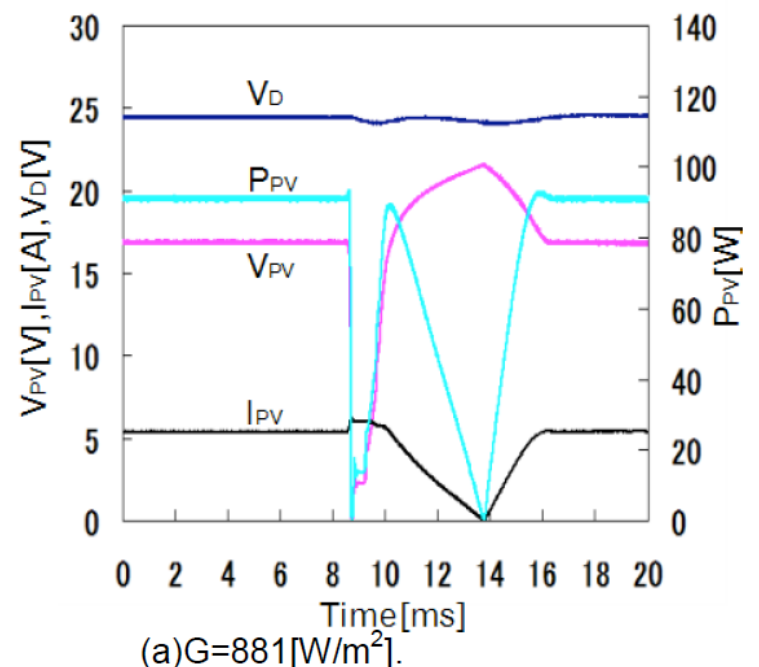

(a) $G=881\left[\mathrm{~W} / \mathrm{m}^{2}\right]$.

Figure 5: Detecting waveforms $(\mathrm{Ts}=5.0[\mathrm{~ms}])$.

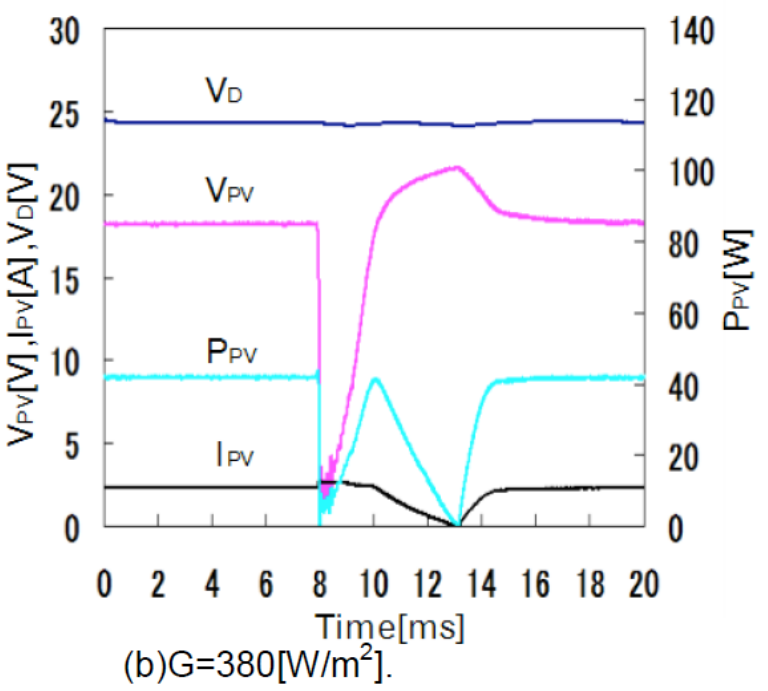




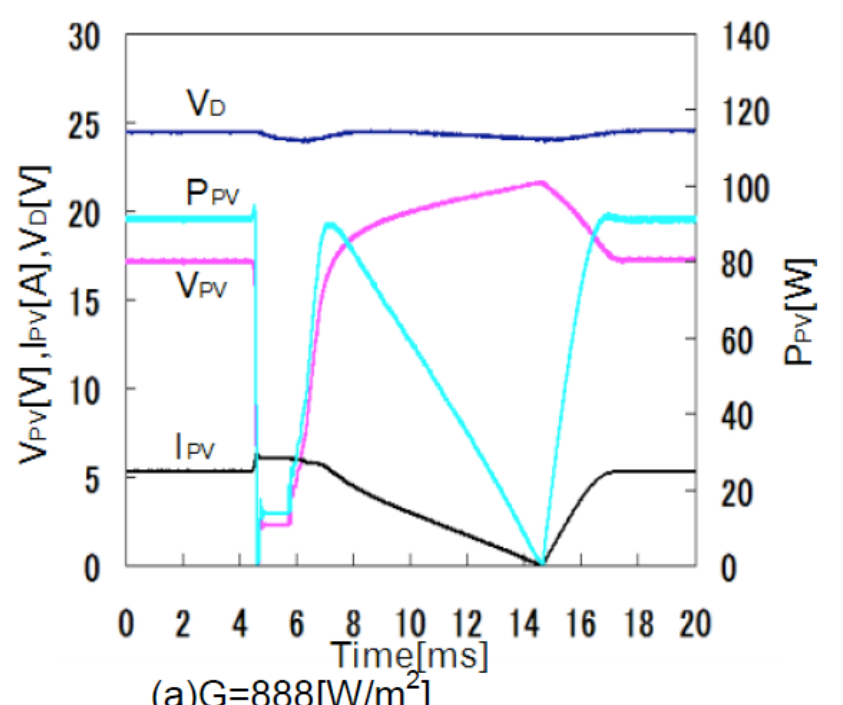

(a) $\mathrm{G}=888\left[\mathrm{~W} / \mathrm{m}^{2}\right]$

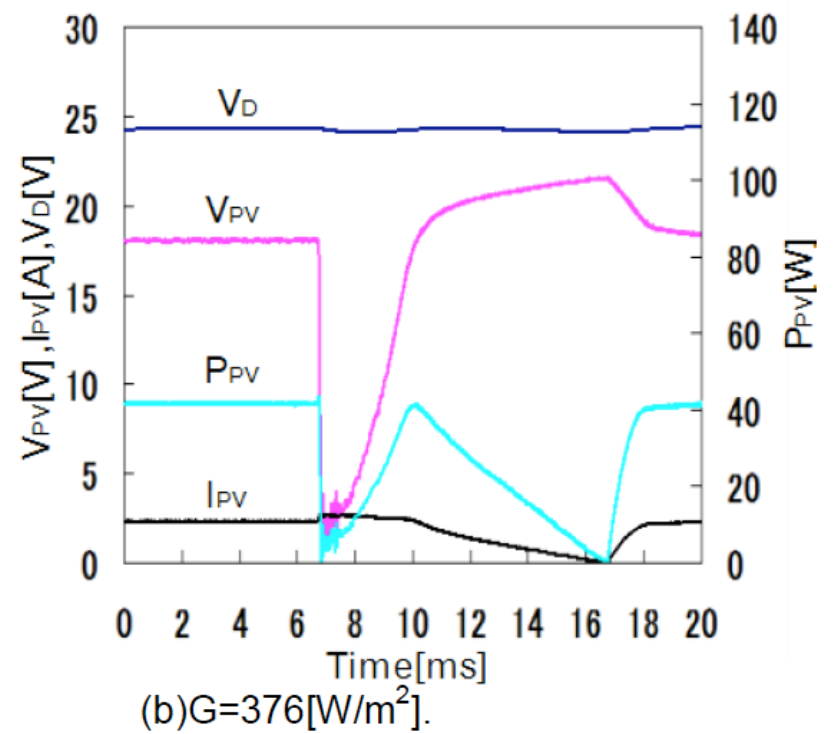

Figure 6: Detecting waveforms (Ts=10.0 [ms]).

high-voltage side, even when partial shading is applied. The powers generated during partial shading were 72.3W and 15.1W with the proposed MPPT control method and the conventional P\&O method, respectively.

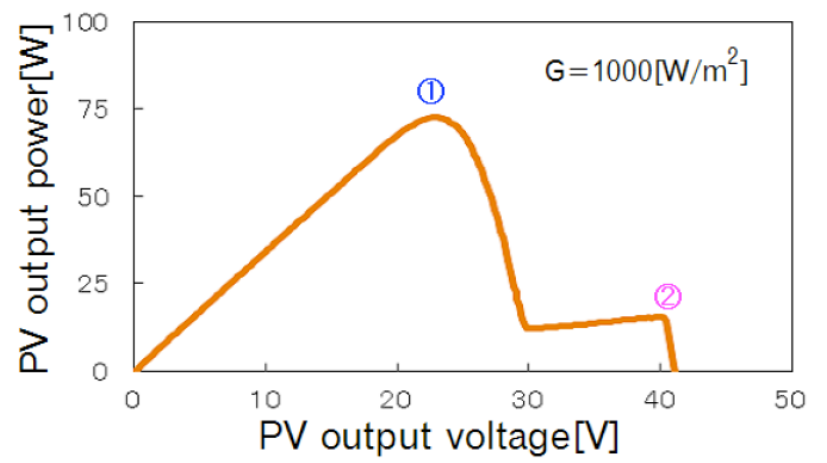

Figure 7: P-V characteristics with partial shading.

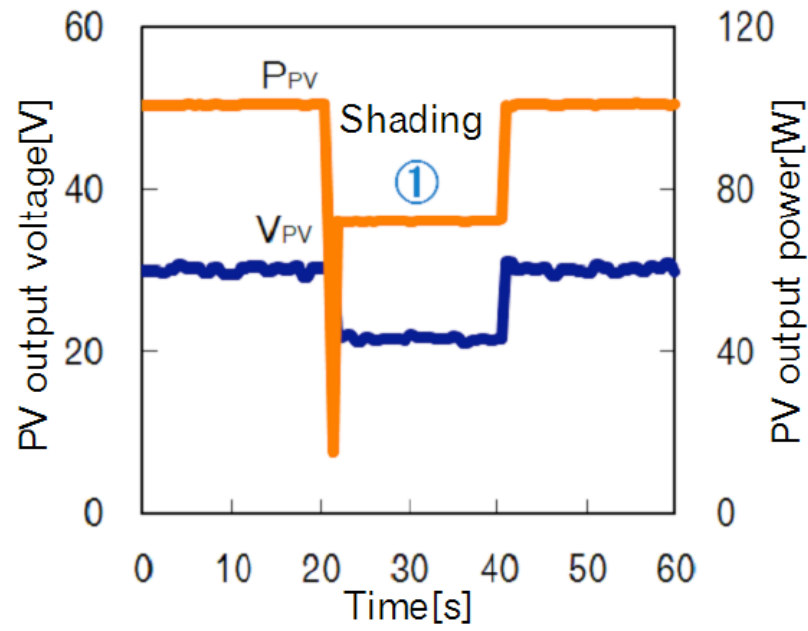

(a)Proposed MPPT control.

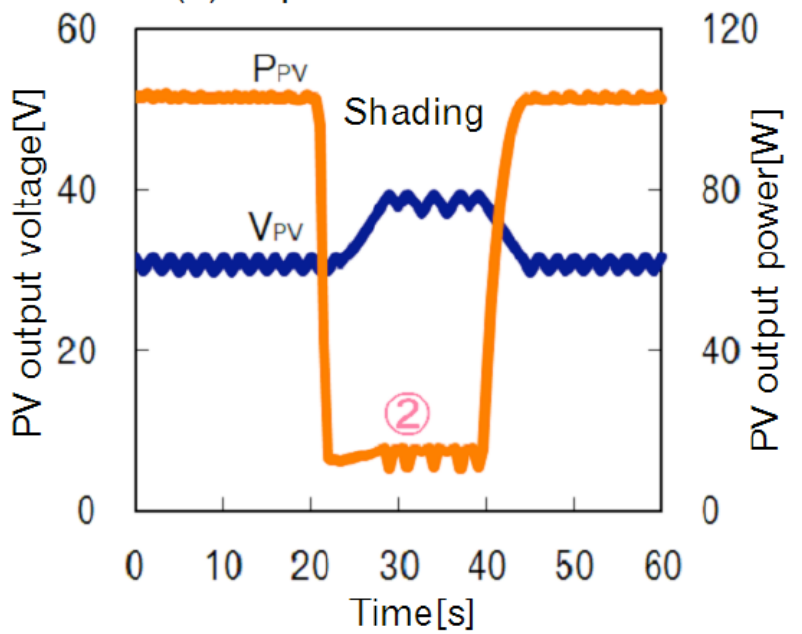

(b)Conventional P\&O method.

Figure 8: Operating waveforms when partial shading is applied.

\section{CONCLUSIONS}

This paper proposes the new scanning interval control method in I-V characteristics scan-type MPPT control for a PV generation system. From the experimental results, it is clarified that even if the value of $L$ is low, the set detecting interval can be assured regardless of difference of the solar radiation intensity, and that the new MPPT control offers outstanding effectiveness in partially shaded environments.

\section{REFERENCES}

[1] Leonhard W. Control of Electrical Drives $3^{\text {rd }}$ ed. Springer 2001 ; p. 317. http://dx.doi.org/10.1007/978-3-642-56649-3

[2] Maheshppa HD, Nagaraju J, Krishna Murthy MV. An Improved Maximum Power Point Tracker Using a Step Up Converter with Current Locked Loop. Renewable Energy 1998; 13(2): 195-201.

http://dx.doi.org/10.1016/S0960-1481(97)00071-2 
[3] Hiyama T, Kouzuma S, Imakubo T. Identification of Optimal Operating Point of PV Modules using Neural Network for Real Time Maximum Power Tracking Control. IEEE Trans Energy Convertion 1995; 10(2).

[4] Hiyama T, Kouzuma S, Imakubo T, Ortmeyer TH. Evaluation of Neural Network Based Real Time Maximum Power Tracking Controller for PV System. IEEE Trans Energy Convertion 1995; 10(3).

[5] Base BK, Szczesny PM, Steigerwald RL. Microcomputer Control of a Residential Power Conditioning System. IEEE Trans Ind Aplicat 1985; IA-21: 1182-91. http://dx.doi.org/10.1109/TIA.1985.349522

[6] Hua C, Lin J, Shen C. Implementation of a DSP-controlled Photovoltaic System with Peak Power Tracking. IEEE Trans Ind Electron 1998; 45: 99-107. http://dx.doi.org/10.1109/41.661310

[7] Koutroulis E, Kalaitzakis K, Voulgaris NC. Development of a Microcontroller-Based, Photovoltaic Maximum Power Point Tracking Control System. IEEE Trans Power Electron 2001; 16(1): 46-54. http://dx.doi.org/10.1109/63.903988

[8] Itako K, Mori T. A New Current Sensorless MPPT Control Method for PV Generation Systems. Proceedings of $11^{\text {th }}$
European Conference on Power Electronics and Applications 2005.

http://dx.doi.org/10.1109/EPE.2005.219250

[9] Itako K, Mori T. A Current Sensorless MPPT Control Method for a Stand-Alone-Type PV Generation System. Electrical Engineering in Japan, WILEY(USA) 2006; 157(2): 65-71. http://dx.doi.org/10.1002/eej.20424

[10] Itako K, Mori T. A New MPPT control method for PV generation systems. The International Conference on Electrical Engineering 2006.

[11] Itako K, Mori T. A Single Sensor Type MPPT Control Method for PV Generation Systems. Proceedings of $12^{\text {th }}$ European Conference on Power Electronics and Applications 2007.

[12] Itako K, Daidouji S, Mori T. A Study on Reduction of $L$ for MPPT Control with I-V Characteristics Scanning. J Jpn Solar Energy Soc 36(2): 45-50.

[13] Itako K, Torii T, Watanabe M. Detecting Interval Control in MPPT Control with I-V Characteristics Scanning for a PV Generation System, Proceedings of JSES/JWEA Joint Conference, 2010; 138. 